\title{
Water quality index to determine the surface water quality of Sankey tank and Mallathahalli lake, Bangalore urban district, Karnataka, India
}

\author{
P. Ravikumar • Mohammad Aneesul Mehmood • \\ R. K. Somashekar
}

Received: 7 October 2012/Accepted: 2 January 2013/Published online: 24 January 2013

(c) The Author(s) 2013. This article is published with open access at Springerlink.com

\begin{abstract}
The present work aims at assessing the water quality index (WQI) in the surface water of Sankey tank and Mallathahalli lake situated in Bangalore Urban district by monitoring three sampling locations within Sankey tank (viz., A, B and C) and Mallathahalli lake (viz., Inlet, Centre and outlet) for a period of 3 months from March to May 2012. The surface water samples were subjected to comprehensive physico-chemical analysis involving major cations $\left(\mathrm{Ca}^{2+}, \mathrm{Mg}^{2+}, \mathrm{Na}^{+}, \mathrm{K}^{+}, \mathrm{Fe}^{2+}\right)$, anions $\left(\mathrm{HCO}_{3}{ }^{-}\right.$, $\mathrm{Cl}^{-}, \mathrm{SO}_{4}{ }^{2-}, \mathrm{NO}_{3}{ }^{-}, \mathrm{F}^{-}, \mathrm{PO}_{4}{ }^{3-}$ ) besides general parameters (pH, EC, TDS, alkalinity, total hardness, DO, BOD, COD, $\mathrm{CO}_{2}, \mathrm{SiO}_{2}$, colour, turbidity). For calculating the WQI, 14 parameters namely, $\mathrm{pH}$, electrical conductivity, total dissolved solids, total hardness, alkalinity, calcium, magnesium, sodium, potassium, chloride, sulphate, nitrate, fluorides and iron were considered. SAR values indicated that both Sankey tank and Mallathahalli lake waters are excellent (S1) for irrigation, while electrical conductivity values classified these lake water, respectively under medium salinity (C2) and high (C3) salinity category. Correlation between SAR and electrical conductivity revealed that Sankey tank water is C2S1 (medium salinitylow sodium) type while Mallathahalli lake water is C3S1 (high salinity-low sodium) type. Sankey tank and Mallathahalli lake water were, respectively hard and very hard in nature. Further, it is apparent from WQI values that Sankey tank water belongs to good water class with WQI values ranging from 50.34 to 63.38 . The Mallathahalli lake water with WQI value ranging from 111.69 to 137.09 , fall under poor water category.
\end{abstract}

P. Ravikumar $(\varangle) \cdot$ M. Aneesul Mehmood · R. K. Somashekar Department of Environmental Science, Bangalore University, Bangalore 560056, India

e-mail: prakruthiravi@gmail.com; nisargaravi@gmail.com
Keywords Sankey tank - Mallathahalli lake . Water quality index $\cdot$ SAR $\cdot$ Percent sodium

\section{Introduction}

Lakes and tanks are known to be ecological barometers of the health of a city as they regulate the micro-climate of any urban center (Benjamin et al. 1996), thereby influencing the life of the people adjacent to it. The quality of surface water in an inland water bodies have a profound effect on the ground water table and ground water quality of the nearby aquifers due to existence of direct interaction between surface and ground water. Lakes have a great significance environmentally due to reasons such as (a) sources of water: surface and groundwater recharge and discharge, for drinking and irrigation, (b) supports livelihoods, lung space of clear and cool air, (c) food and nutrition, (d) act as flood control and stream flow maintenance, (e) recreation-education, boating, swimming, walking and jogging on the lake bund, (f) lakes are natural infrastructure for climate change adaptation and biogeological cycles, (g) pisciculture, (h) wildlife habitat, especially fishes and birds, (i) rain water harvesting and, (j) emergency water supply for firefighting.

The environmental conditions of any lake system depend upon the nature of that lake and its exposure to various environmental factors. Hence, surface water quality depends not only on natural processes (precipitation inputs, erosion, and weathering of crustal material, etc.) but also on anthropogenic influences (urban, industrial, and agricultural activities) (Papatheodorou et al. 2006). Their fragile ecosystem must maintain the state of environmental equilibrium with the existing surroundings particularly from a special prospective of human encroachment and 
pollution. However, in recent decades, population growth, agricultural practices and sewage runoff from urban areas have increased nutrient inputs many folds to the level of their natural occurrence, resulting in accelerated eutrophication (Choudhary et al. 2010; Zan et al. 2010). The lakes and reservoirs, all over India without exception, are in varying degrees of environmental degradation, might be due to encroachments, eutrophication (from domestic and industrial effluents) and silt. There has been a quantum jump in population during the last century without corresponding expansion of civic facilities resulting in lakes and reservoirs, especially the urban ones, becoming sinks for contaminants. Most urban and rural lakes have vanished under this pressure with worldwide environmental concerns (Iscen et al. 2008; Prasanna et al. 2010). However, in those lakes that could endure, drinking water supply is either substantially reduced or is non-potable, flood absorption capacity impaired, biodiversity threatened and there is diminished fish production (Zhang et al. 2009). The main reasons which resulted in impaired conditions of the lakes could be categorized into two classes namely, (a) pollutants entering from fixed point sources (viz., $n$ utrients from wastewater, from municipal and domestic effluents; organic, inorganic and toxic pollutants from industrial effluents and storm water runoff) (b) pollutants entering from non-point sources (viz., nutrients through fertilizers, toxic pesticides and other chemicals, mainly from agriculture runoff; organic pollution from human settlements spread over areas along the periphery of the lakes and reservoirs).

Developmental pressures and increasing human population has made the lakes of the study area vulnerable to sewage flow, solid waste dumping, etc., in turn exerting pressure on the percolation and infiltration processes responsible for the groundwater recharge (Ravikumar et al. 2011). The municipal effluents from such natural drains leading to tanks and lakes deteriorated the quality of these water bodies. Sedimentation of the pollutants has not only reduced the surface area of the water which in turn has increased evaporation rate, but also reduced ground water levels on account of poor permeability with more and more silt, clay deposits, trash and toxic waste accumulation in them year after year. In spite of the fact that nutrient enrichment stimulates the growth of plants (algae as well as higher plants), nutrient enrichment in lakes is considered as one of the major environmental problems in many countries (Oczkowski and Nixon 2008), ultimately leading to deterioration of water quality and degradation of entire ecosystems ( $\mathrm{Yu}$ et al. 2010). Hence, periodic monitoring and assessment of water quality helps to develop management strategies to control surface water pollution (Shuchun et al. 2010) in spite of increasing urbanization and anthropogenic pressure on them. Water quality index
(WQI) is one of the most effective tools (Mishra and Patel 2001; Naik and Purohit 2001; Singh 1992; Tiwari and Mishra 1985) to communicate information on the quality of water to the concerned citizens and policy makers as it is an important parameter for the assessment and management of surface/ground waters. Hence, the present work has been carried out with a focus to evaluate comparatively the prevailing water quality and potability of two lakes, Mallathahalli lake (viz., sewage fed lake) and Sankey tank (viz., rainfed lake) by analyzing physico-chemical parameters and by estimating WQI.

\section{Study area}

Bangalore district is situated in the heart of the SouthDeccan plateau in peninsular India to the South-Eastern corner of Karnataka State between the latitudinal parallels of $12^{\circ} 39^{\prime} \mathrm{N}$ and $13^{\circ} 18^{\prime} \mathrm{N}$ and longitudinal meridians of $77^{\circ} 22^{\prime} \mathrm{E}$ and $77^{\circ} 52^{\prime} \mathrm{E}$ at an average elevation of about $920 \mathrm{~m}(3,020 \mathrm{ft})$ covering an areal extent of land of about $2,174 \mathrm{~km}^{2}$ (Bangalore rural and urban districts). Bangalore district (Bangalore rural and urban districts) borders with Kolar and Chikkaballapur in the northeast, Tumkur in the northwest, Mandya and Ramanagaram in the southeast and Mysore and Tamil Nadu in the south. Bangalore urban district is bounded in all the directions by Bangalore rural district except in southeast, where the district is bounded by Dharmapuri district of Tamil Nadu state. Bangalore urban district divided into three taluks namely Bangalore North, Bangalore South and Anekal (Fig. 1). Major part of the district (viz., Bangalore north and South taluks) is drained by Shimsha and Kanva rivers of Cauvery basin (Catchment area of $468 \mathrm{~km}^{2}$, which includes Nelamangala and Magadi taluks of Bangalore rural also). Anekal taluk is drained by South Pennar river of Ponnaiyar basin, which takes its birth from Nandi hills and flows toward south (Catchment area is $2,005 \mathrm{~km}^{2}$ which covers Devanahalli and Hoskote taluks of Bangalore rural district also). Bangalore is considered to be climatically a well favoured district. The climate of the district is classed as the seasonally dry tropical Savanna climate with four seasons. The main features of the climate of Bangalore are agreeable and favourable range of temperatures. The dry season with clear bright summer weather (December to February), is characterized by high temperatures (March to May), followed by the South-West monsoon season (June to September) and post-monsoon/retreating monsoon season (October to November). Two rainy seasons come one after the other but with opposite wind regimes, corresponding to the south-west and north-east monsoons. Typical monsoonal climate prevails in the district with major contribution of rainfall from southwest monsoon. Contribution 


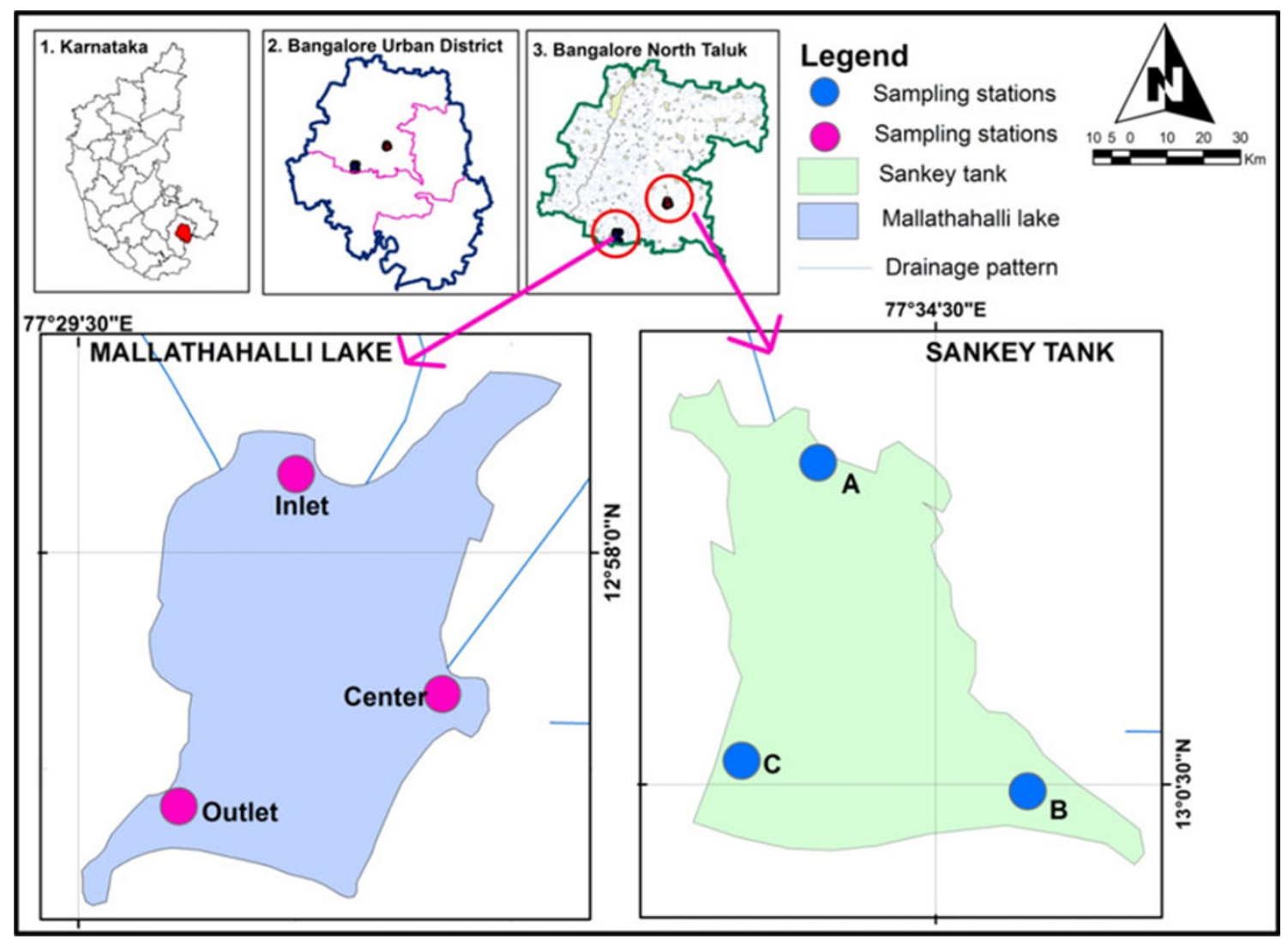

Fig. 1 Location map of Sankey tank and Mallathahalli Lake

from south-west monsoon and north-east monsoon respectively account for 54.18 and $26.53 \%$ of the total rainfall in addition to the significant contribution of $18.53 \%$ from pre-monsoon showers. In general, pre-humid to semi-arid climatic conditions prevail in the district. The mean annual rainfall is $859.6 \mathrm{~mm}$, with three different rainy periods covering 8 months of the year. June to September being rainy season receives $54 \%$ of the total annual rainfall in the S-W monsoon period and $241 \mathrm{~mm}$ during the N-E monsoon period (October-November). Bangalore records high temperatures during April with daily mean temperatures of $33.4{ }^{\circ} \mathrm{C}$ and mean daily minimum in the month of December at $25.7^{\circ} \mathrm{C}$, as the coolest month. The mean monthly relative humidity is the lowest during the month of March at $44 \%$ and records highest between the months of June and October at $80-85 \%$. The surface winds in Bangalore have seasonal characteristics with the easterly components predominating during one period followed by the westerly in the other. The high wind speed averages $17 \mathrm{~km} / \mathrm{h}$ during the westerly winds in the month of July and a minimum of $8-9 \mathrm{~km} / \mathrm{h}$ during the months of April and October.

Two surface water bodies namely Mallathahalli lake (viz., sewage fed lake) and Sankey tank (viz., rainfed lake) were opted for the present study (Fig. 1).
A. Sankey tank, a man-made freshwater lake or tank, situated in the western part of Bangalore in the middle of the suburbs of Malleshwaram, Vyalikaval and Sadashiva Nagar, lying in an highly urbanized area. The lake covers a surface area of about 15 ha (37.1 acres) and catchment area of $1.254 \mathrm{~km}(0.8$ mile) with one island within its premise. It is a part of Vrishabhavathi valley in the Bangalore urban district with rainfall being primary inflow into it and has got one outlet on the southern corner. At its widest, the tank has a width of $800 \mathrm{~m}(2,624.7 \mathrm{ft})$ and a maximum depth of $9.26 \mathrm{~m}(30.4 \mathrm{ft})$. The highest point was $929.8 \mathrm{~m}$ above mean sea level. The tank was also known as Gandhadhakotikere, as the Government Sandalwood Depot is located near the lake. This tank was recently brought under restoration programme of BBMP (Bruhat Bangalore Mahanagara Palike) by Bangalore Water Supply and Sewerage Board (BWSSB) with other major implementations such as removing encroachments, alum purification treatment to absorb toxic elements and germs, nursery towards the north, paved walkways, landscaped parks, special tank for idol immersion during Ganesh Chaturthi festival and restoration of swimming pool. The threats posed to the survival of 
the lake includes (a) contamination of water with sewage flowing in from seven points, which are connected to storm water drains, (b) choked drains with garbage and sewage, (c) leaking sewage pipes connected to a public toilet at a park, (d) decrease in the biological oxygen demand (viz., high BOD content) due to sewage inflow, (e) threats to fish and plants and reduction in number of ducks, fish and migratory birds due to polluted condition of the lake waters (viz., DO was reported to vary from 3.7 to 8.1 , BOD between 2 and 8 and the $\mathrm{pH}$ varied from 7.1 to 7.5$)$.

(B) Mallathahalli lake is freshwater, natural lake located on the western fringe of Bangalore city in less urbanized area. Mallathahalli lake fall in Vrishabhavathi valley and Byramangala lake series in the Bangalore urban district and the main primary source of water to the lake are rainfall and sewage. The inlets are at the north and north-east corners of the lake while one outlet is also there on the northwestern corner of lake. The lake is irregular in shape and covers approximately 25.9 ha surface area and perimeter being approximately $2,900 \mathrm{~m}$, while digitized lake boundary through RS and GIS gave an area of 27.53 ha. It was observed that the lake area has reduced from 27.53 ha to 25.95 ha. The catchment area of the lake is about 625 ha with 3 islands within its premises. The highest point was $900 \mathrm{~m}$ above sea level and lowest point was $840 \mathrm{~m}$ above mean sea level. Mallathahalli lake is affected by several sources of pollution including washing of clothes, animals, vehicles and even bathing, especially on the northern and eastern banks of the lake. These activities lead to pollution of the lake by soaps, detergents and organic matter, and are taking place almost all around the lake. The lake area is also misused as public toilets leading to unhygienic environment and increasing the organic load in the lake. To the south of the lake, its banks are used as crematorium. Dumping of garbage and other wastes around the lake is taking place, which not only pollutes the lake but also spoils its beauty. To the west of the lake, there is an Areca plantation surrounded by several housing encroachments. The sewage line enters the lake from north-east and eastern banks of the lake. Cattle grazing can be seen to the west and north of the lake. The volume of the lake is decreasing due to the accumulation of silt coming from the run off. There are a number of upcoming layouts around the lake, which may affect the water both quantitatively and qualitatively.

\section{Methodology}

Sampling of surface water

The surface water samples collected at three different sites within the Sankey tank are earmarked as A, B, and C, while the three sample collection centers from Mallathahalli lake were assigned the names inlet, centre and outlet. The collected surface water samples were collected from these six locations in a $2 \mathrm{~L}$ pre-cleaned polyethylene bottles for a period of 3 months from March 2012 to May 2012. Three months' continuous monitoring involved comprehensive physicochemical analyses encompassing estimation of major cations $\left(\mathrm{Ca}^{2+}, \mathrm{Mg}^{2+}, \mathrm{Na}^{+}, \mathrm{K}^{+}, \mathrm{Fe}^{2+}\right)$, anions $\left(\mathrm{HCO}_{3}{ }^{-}, \mathrm{Cl}^{-}, \mathrm{SO}_{4}{ }^{2-}\right.$, $\mathrm{NO}_{3}{ }^{-}, \mathrm{F}^{-}, \mathrm{PO}_{4}{ }^{3-}$ ) besides general parameters ( $\mathrm{pH}, \mathrm{EC}, \mathrm{TDS}$, alkalinity, total hardness, $\mathrm{DO}, \mathrm{BOD}, \mathrm{COD}, \mathrm{CO}_{2}, \mathrm{SiO}_{2}$, colour, turbidity, temperature). In situ parameters like $\mathrm{pH}, \mathrm{EC}, \mathrm{TDS}$, dissolved oxygen, etc. were measured immediately in the field immediately after sampling. The standard analytical procedures as recommended by the American Public Health Association (2005) were employed in the present study (Table 1). Sample from each station within the lake were analyzed thrice for each parameters (i.e., triplicate results) to obtain concordant values. Based on the results of physicochemical analyses, irrigation quality parameters like sodium absorption ratio (SAR), percent sodium (\% $\mathrm{Na}$ ), residual sodium carbonate (RSC) were also calculated. The suitability of the surface water from these two lakes for drinking, domestic, and irrigation purposes was evaluated by comparing the values of different water quality parameters with those of the Bureau of Indian standards (BIS 1998) guideline values for drinking water.

\section{Water quality index}

The WQI provides a comprehensive picture of the quality of surface/ground water for most domestic uses. WQI is defined as a rating that reflects the composite influence of different water quality parameters (Sahu and Sikdar 2008). WQI is calculated from the point of view of the suitability of surface and/or groundwater for human consumption. Hence, for calculating the WQI in the present study, 14 parameters namely, $\mathrm{pH}$, electrical conductivity, total dissolved solids, total hardness, alkalinity, calcium, magnesium, sodium, potassium, chloride, sulphate, nitrate, fluorides and iron have been considered (Table 2).

There were three steps for computing WQI of a water sample.

a. Each of the chemical parameters was assigned a weight $\left(w_{i}\right)$ based on their perceived effects on primary health/ their relative importance in the overall quality of water 
Table 1 Analytical methods adopted along with the BIS desirable and permissible limits

\begin{tabular}{|c|c|c|c|c|c|c|}
\hline \multirow[t]{2}{*}{ Sl. No } & \multirow{2}{*}{$\begin{array}{l}\text { Category } \\
\text { of } \\
\text { parameters }\end{array}$} & \multirow[t]{2}{*}{ Characteristics } & \multirow[t]{2}{*}{ Analytical method } & \multirow[t]{2}{*}{ Unit } & \multicolumn{2}{|c|}{ BIS limits (1998) } \\
\hline & & & & & Desirable & Permissible \\
\hline 1 & General & $\mathrm{pH}$ & Electrode & - & $6.5-8.5$ & $6.5-8.5$ \\
\hline 2 & & $\begin{array}{l}\text { Electrical } \\
\text { conductivity } \\
\text { (EC) }\end{array}$ & Conductivity-TDS meter & $\mu \mathrm{S} / \mathrm{cm}$ & 2,000 & 3,000 \\
\hline 3 & & $\begin{array}{l}\text { Total dissolved } \\
\text { solids (TDS) }\end{array}$ & Conductivity-TDS meter & $\mathrm{mg} / \mathrm{L}$ & 1,000 & 2,000 \\
\hline 4 & & $\begin{array}{l}\text { Total Alkalinity } \\
\text { (as } \mathrm{CaCO}_{3}^{-} \text {) }\end{array}$ & Titrimetric & $\mathrm{mg} / \mathrm{L}$ & 200 & 600 \\
\hline 5 & & Temperature & Electrode & ${ }^{\circ} \mathrm{C}$ & NA & NA \\
\hline 6 & & $\begin{array}{l}\text { Total hardness } \\
\text { (as } \mathrm{CaCO}_{3} \text { ) }\end{array}$ & EDTA titrimetric & $\mathrm{mg} / \mathrm{L}$ & 300 & 600 \\
\hline 7 & & $\begin{array}{l}\text { Calcium } \\
\text { hardness } \\
\left(\text { as } \mathrm{CaCO}_{3}\right)\end{array}$ & EDTA titrimetric & $\mathrm{mg} / \mathrm{L}$ & 75 & 200 \\
\hline 8 & & Colour & Colorimetric & Hazens & 10 & 25 \\
\hline 9 & & Turbidity & Colorimetric & NTU & 5 & 10 \\
\hline 10 & & $\begin{array}{l}\text { Dissolved } \\
\text { oxygen (DO) }\end{array}$ & Modified Winker's method & $\mathrm{mg} / \mathrm{L}$ & 6.0 & NA \\
\hline 11 & & $\begin{array}{l}\text { Biochemical } \\
\text { oxygen } \\
\text { demand (BOD) }\end{array}$ & Modified Winker's method & $\mathrm{mg} / \mathrm{L}$ & 3.0 & 6.0 \\
\hline 12 & & $\begin{array}{r}\text { Chemical oxygen } \\
\text { demand (COD) }\end{array}$ & Closed reflux method & $\mathrm{mg} / \mathrm{L}$ & NA & NA \\
\hline 13 & $\begin{array}{l}\text { Major } \\
\text { cations }\end{array}$ & $\begin{array}{l}\text { Calcium } \\
\quad\left(\text { as }^{2+}\right)^{2+}\end{array}$ & EDTA titrimetric & $\mathrm{mg} / \mathrm{L}$ & 75 & 200 \\
\hline 14 & & $\begin{array}{l}\text { Magnesium } \\
\quad\left(\text { as } \mathrm{Mg}^{2+}\right)\end{array}$ & EDTA titrimetric & $\mathrm{mg} / \mathrm{L}$ & 30 & 100 \\
\hline 15 & & Sodium $\left(\right.$ as $\left.\mathrm{Na}^{+}\right)$ & Flame photometric & $\mathrm{mg} / \mathrm{L}$ & 100 & 200 \\
\hline 16 & & $\begin{array}{l}\text { Potassium } \\
\quad\left(\text { as } \mathrm{K}^{2+}\right)\end{array}$ & Flame photometric & $\mathrm{mg} / \mathrm{L}$ & 10 & 10 \\
\hline 17 & & $\begin{array}{l}\text { Ferrous iron } \\
\quad\left(\text { as } \mathrm{Fe}^{2+}\right)\end{array}$ & $\begin{array}{l}\text { 1,10 Phenanthroline method } \\
\text { using HACH colorimeter } \\
\text { (DR/890) }\end{array}$ & $\mathrm{mg} / \mathrm{L}$ & 0.3 & 1.0 \\
\hline 18 & $\begin{array}{l}\text { Major } \\
\text { anions }\end{array}$ & $\begin{array}{l}\text { Bicarbonates } \\
\quad\left(\text { as } \mathrm{HCO}_{3}{ }^{-}\right)\end{array}$ & Titrimetric & $\mathrm{mg} / \mathrm{L}$ & NA & NA \\
\hline 19 & & $\begin{array}{l}\text { Carbonates } \\
\quad\left(\text { as } \mathrm{CO}_{3}{ }^{2-}\right)\end{array}$ & Titrimetric & $\mathrm{mg} / \mathrm{L}$ & NA & NA \\
\hline 20 & & Chlorides & Argentometric titration & $\mathrm{mg} / \mathrm{L}$ & 250 & 1,000 \\
\hline 21 & & $\begin{array}{l}\text { Nitrates } \\
\quad\left(\text { as } \mathrm{NO}_{3}{ }^{-}\right)\end{array}$ & Ion selective electrode (ISE) & $\mathrm{mg} / \mathrm{L}$ & 45 & 45 \\
\hline 22 & & Fluoride $\left(\right.$ as $\mathrm{F}^{-}$) & Ion selective electrode (ISE) & $\mathrm{mg} / \mathrm{L}$ & 1.0 & 1.5 \\
\hline 23 & & $\begin{array}{l}\text { Phosphates } \\
\quad\left(\text { as } \mathrm{PO}_{4}{ }^{3-}\right)\end{array}$ & Stannous chloride & $\mathrm{mg} / \mathrm{L}$ & 0.3 & 0.3 \\
\hline 24 & & $\begin{array}{l}\text { Sulphates } \\
\quad\left(\text { as } \mathrm{SO}_{4}{ }^{2-}\right)\end{array}$ & Barium chloride & $\mathrm{mg} / \mathrm{L}$ & 200 & 400 \\
\hline
\end{tabular}

for drinking purposes (Table 2). The highest weight of 5 was assigned to parameters which have the major effects on water quality and their importance in quality (viz., $\mathrm{NO}_{3}{ }^{-}, \mathrm{F}^{-}$and TDS) and a minimum of 2 was assigned to parameters which are considered as not harmful $\left(\mathrm{Ca}^{2+}, \mathrm{Mg}^{2+}, \mathrm{K}^{+}\right)$. b. Computing the relative weight $\left(W_{i}\right)$ of each parameter using Eq. 1. Table 2 present the weight $\left(w_{i}\right)$ and calculated relative weight $\left(W_{i}\right)$ values for each parameter.

c. A quality rating scale $\left(q_{i}\right)$ for each parameter is computed by dividing its concentration in each water sample by its respective standard according to the 
Table 2 The weight and relative weight of each of the physicochemical parameters used for WQI determination

\begin{tabular}{llll}
\hline Parameters & $\begin{array}{l}\text { BIS } \\
\text { desirable } \\
\text { limit }(1998)\end{array}$ & $\begin{array}{l}\text { Weight } \\
\left(w_{i}\right)\end{array}$ & $\begin{array}{l}\text { Relative } \\
\text { weight }\left(W_{i}\right)\end{array}$ \\
\hline $\mathrm{pH}$ & 8.5 & 3 & 0.0698 \\
$\mathrm{EC}$ & 2,000 & 3 & 0.0698 \\
Total dissolved solids & 1,000 & 5 & 0.1163 \\
$\quad$ TDS) & & & \\
Total alkalinity (TA) & 200 & 2 & 0.0465 \\
Total hardness (TH) & 300 & 3 & 0.0698 \\
Calcium & 75 & 2 & 0.0465 \\
Magnesium & 30 & 2 & 0.0465 \\
Sodium & 100 & 3 & 0.0698 \\
Potassium & 10 & 2 & 0.0465 \\
Chloride & 250 & 3 & 0.0698 \\
Sulphate & 200 & 3 & 0.0698 \\
Nitrate & 45 & 5 & 0.1163 \\
Fluoride & 1 & 5 & 0.1163 \\
Iron & 0.3 & 2 & 0.0465 \\
& - & $\sum w_{i}=43$ & $\sum W_{i}=1.000$ \\
\hline
\end{tabular}

guidelines laid down by BIS (1998) and then, the result was multiplied by 100 using Eq. 2. Finally, for computing the WQI, the water quality sub-index $\left(\mathrm{SI}_{i}\right)$ for each chemical parameter is first determined, which is then used to determine the WQI as per the Eqs. 3 and 4.

$W_{i}=\frac{w_{i}}{\sum_{n=1}^{n} w_{i}}$

where $W_{i}$ is the relative weight, $w_{i}$ is the weight of each parameter and $n$ is the number of parameters.

$q_{i}=\left(\frac{C_{i}}{S_{i}}\right) 100$

where $q_{i}=$ quality rating, $C_{i}=$ concentration of each chemical parameter in each water sample in $\mathrm{mg} / \mathrm{L}, \mathrm{S}_{i}=$ Indian drinking water standard (BIS 1998) for each chemical parameter in $\mathrm{mg} / \mathrm{L}$ except for conductivity $(\mu \mathrm{S} / \mathrm{cm})$ and $\mathrm{pH}$.

$\mathrm{SI}=W_{i} q_{i}$

$\mathrm{WQI}=\sum_{i=1}^{n} \mathrm{SI}_{i}$

where $\mathrm{SI}_{i}$ is the sub-index of $i$ th parameter; $q_{i}$ is the rating based on concentration of $i$ th parameter and $n$ is the number of parameters.

\section{Results and discussion}

The samples were collected from each of the three different sites within the Sankey tank (earmarked as A, B, and C) and Mallathahalli lake (assigned as inlet, centre, and outlet) and each sample was analyzed thrice for the period March, April and May 2012. The minimum, maximum and mean analytical results for each parameter for each period of analysis (i.e., March, April and May 2012) for both Sankey tank and Mallathahalli lake are summarized in Tables 3 and 4 , respectively.

$\mathrm{pH}$ is a numerical expression that indicates the degree to which water is acidic or alkaline, with the lower $\mathrm{pH}$ value tends to make water corrosive and higher $\mathrm{pH}$ provides taste complaint and negative impact on skin and eyes (Rao and Rao 2010). The mean $\mathrm{pH}$ of Sankey tank water was $8.76 \pm 0.73$ (March 2012), $8.54 \pm 0.40$ (April 2012) and $8.30 \pm 0.18$ (May 2012) while the mean $\mathrm{pH}$ of Mallathahalli lake water was $8.65 \pm 0.34$ (March 2012), $8.78 \pm 0.73$ (April 2012) and $8.94 \pm 0.53$ (May 2012). Garg et al. (2010) opines that $\mathrm{pH}$ range between 6.0 and 8.5 indicates the productive nature of any water body. But, $\mathrm{pH}$ of both the lakes in the present study crossed the permissible limit of 6.5-8.5 (BIS 1998).

Electrical conductivity of water is a direct function of its total dissolved salts (Harilal et al. 2004) and is used as an index to represent the total concentration of soluble salts in water (Purandara et al. 2003; Gupta et al. 2008). Excess EC lead to scaling in boilers, corrosion and quality degradation of the product. The mean conductivity values was $462.56 \pm 68.82 \mu \mathrm{S} / \mathrm{cm}$ (March 2012), $482.22 \pm 79.06$ $\mu \mathrm{S} / \mathrm{cm}$ (April 2012) and $384.67 \pm 41.80 \mu \mathrm{S} / \mathrm{cm}$ (May 2012) in Sankey tank water and 1,762.56 $\pm 79.20 \mu \mathrm{S} / \mathrm{cm}$ (March 2012), 1,777.89 $\pm 32.62 \mu \mathrm{S} / \mathrm{cm}$ (April 2012) and $1853.33 \pm 66.56 \mu \mathrm{S} / \mathrm{cm}$ (May 2012) in Mallathahalli lake water. Conductivity value of Sankey tank and Mallathahalli lake water were well within the permissible limit of $3,000 \mu \mathrm{S} / \mathrm{cm}$. Relatively higher EC values were recorded in the Mallathahalli Lake water, attributed to the high degree of anthropogenic activities such as waste disposal, sewage inflow and agricultural runoff (Pandit 2002). Classification of water based on Electrical conductivity illustrates that the Sankey tank water belongs to medium salinity class (C2) and Mallathahalli lake water to high (C3) salinity category (Table 5).

Total dissolved solids (TDS) mainly consists of inorganic salts such as carbonates, bicarbonates, chlorides, sulphates, phosphates and nitrates of calcium, magnesium, sodium, potassium, iron etc. and small amount of organic matter. The average concentration of total dissolved solids in Sankey tank water was $286.78 \pm 42.67 \mathrm{mg} / \mathrm{L}$ (March 2012), $298.98 \pm 49.02 \mathrm{mg} / \mathrm{L}$ (April 2012) and $238.49 \pm$ $25.91 \mathrm{mg} / \mathrm{L}$ (May 2012) while in Mallathahalli lake water, it was $1092.78 \pm 49.10 \mathrm{mg} / \mathrm{L}$ (March 2012), $1102.29 \pm$ $20.23 \mathrm{mg} / \mathrm{L}$ (April 2012) and $1149.07 \pm 41.27 \mathrm{mg} / \mathrm{L}$ (May 2012). TDS values of Sankey tank and Mallathahalli lake water were below the BIS permissible limit of $2,000 \mathrm{mg} / \mathrm{L}$. 
Table 3 Analytical results of Sankey tank water from March 2012 to May 2012

\begin{tabular}{|c|c|c|c|c|c|c|c|c|c|c|c|c|}
\hline \multirow[t]{2}{*}{ Parameters } & \multicolumn{4}{|c|}{ March 2012} & \multicolumn{4}{|c|}{ April 2012} & \multicolumn{4}{|c|}{ May 2012} \\
\hline & Mean & SD & Min & $\operatorname{Max}$ & Mean & SD & Min & Max & Mean & SD & Min & Max \\
\hline DO & 7.83 & 1.11 & 6.30 & 9.01 & 7.70 & 1.16 & 5.80 & 9.01 & 6.28 & 0.42 & 5.60 & 6.90 \\
\hline $\mathrm{pH}$ & 8.76 & 0.73 & 7.52 & 9.63 & 8.54 & 0.40 & 8.00 & 9.30 & 8.30 & 0.18 & 8.00 & 8.60 \\
\hline EC & 462.56 & 68.82 & 391.00 & 554.00 & 482.22 & 79.06 & 439.00 & 692.00 & 384.67 & 41.80 & 329.00 & 430.00 \\
\hline TDS & 286.78 & 42.67 & 242.42 & 343.48 & 298.98 & 49.02 & 272.18 & 429.04 & 238.49 & 25.91 & 203.98 & 266.60 \\
\hline Colour & 8.89 & 2.20 & 5.00 & 10.00 & 10.00 & 0.00 & 10.00 & 10.00 & 10.00 & 0.00 & 10.00 & 10.00 \\
\hline Turbidity & 0.90 & 0.30 & 0.10 & 1.00 & 1.00 & 0.00 & 1.00 & 1.00 & 1.00 & 0.00 & 1.00 & 1.00 \\
\hline BOD & 8.05 & 1.18 & 6.77 & 10.20 & 5.78 & 0.58 & 5.01 & 6.51 & 5.87 & 0.57 & 5.30 & 6.90 \\
\hline COD & 71.44 & 12.32 & 50.20 & 85.20 & 37.94 & 1.41 & 35.80 & 39.50 & 21.91 & 3.19 & 16.40 & 26.40 \\
\hline Temp & 28.19 & 0.40 & 27.70 & 29.10 & 30.04 & 0.50 & 29.10 & 31.00 & 30.13 & 0.39 & 29.70 & 31.00 \\
\hline $\mathrm{CO}_{2}$ & 7.29 & 0.64 & 6.20 & 8.00 & 7.50 & 0.60 & 6.50 & 8.50 & 5.99 & 0.34 & 5.40 & 6.50 \\
\hline TA & 158.98 & 20.64 & 131.50 & 196.10 & 359.78 & 40.65 & 328.00 & 452.00 & 318.00 & 18.85 & 285.00 & 336.00 \\
\hline TH & 148.90 & 14.18 & 128.20 & 168.20 & 138.93 & 5.59 & 130.20 & 147.30 & 122.14 & 5.09 & 114.20 & 130.30 \\
\hline $\mathrm{CaH}$ & 92.32 & 1.37 & 91.00 & 95.20 & 57.62 & 6.05 & 47.21 & 63.20 & 38.33 & 5.73 & 32.00 & 46.50 \\
\hline $\mathrm{Ca}^{2+}$ & 36.93 & 0.55 & 36.40 & 38.08 & 23.05 & 2.42 & 18.88 & 25.28 & 15.33 & 2.29 & 12.80 & 18.60 \\
\hline $\mathrm{MgH}$ & 56.58 & 14.33 & 37.00 & 76.20 & 81.31 & 9.16 & 71.00 & 95.29 & 83.81 & 3.92 & 78.40 & 89.80 \\
\hline $\mathrm{Mg}^{2+}$ & 13.80 & 3.50 & 9.03 & 18.59 & 19.84 & 2.24 & 17.32 & 23.25 & 20.45 & 0.96 & 19.13 & 21.91 \\
\hline $\mathrm{Cl}^{-}$ & 55.86 & 12.53 & 42.91 & 71.97 & 141.66 & 9.44 & 127.90 & 154.30 & 112.39 & 6.12 & 100.20 & 119.00 \\
\hline $\mathrm{NO}_{3}^{-}$ & 5.04 & 0.43 & 4.31 & 5.68 & 18.20 & 3.44 & 14.20 & 23.50 & 20.23 & 4.46 & 14.00 & 26.20 \\
\hline $\mathrm{PO}_{4}{ }^{3-}$ & 8.86 & 0.46 & 8.20 & 9.50 & 9.59 & 0.97 & 8.60 & 11.50 & 9.48 & 1.51 & 6.50 & 11.20 \\
\hline $\mathrm{SO}_{4}^{2-}$ & 28.83 & 3.70 & 21.21 & 33.33 & 29.69 & 2.84 & 25.80 & 33.50 & 25.03 & 1.95 & 20.40 & 26.30 \\
\hline $\mathrm{F}^{+}$ & 0.32 & 0.07 & 0.20 & 0.40 & 0.42 & 0.22 & 0.10 & 0.80 & 0.47 & 0.21 & 0.10 & 0.80 \\
\hline $\mathrm{K}^{+}$ & 31.59 & 1.73 & 17.52 & 42.50 & 36.01 & 0.31 & 30.90 & 40.90 & 29.58 & 1.95 & 22.80 & 31.20 \\
\hline $\mathrm{Na}^{+}$ & 45.01 & 3.58 & 41.60 & 51.90 & 55.79 & 5.07 & 50.80 & 65.30 & 50.93 & 1.78 & 48.00 & 52.80 \\
\hline $\mathrm{SiO}_{2}$ & 11.38 & 0.77 & 10.50 & 12.50 & 11.99 & 0.44 & 11.30 & 12.50 & 10.39 & 0.61 & 9.50 & 11.50 \\
\hline $\mathrm{Fe}^{2+}$ & 0.12 & 0.01 & 0.11 & 0.13 & 0.17 & 0.06 & 0.10 & 0.30 & 0.16 & 0.05 & 0.10 & 0.20 \\
\hline $\mathrm{HCO}_{3}{ }^{-}$ & 193.95 & 25.18 & 160.43 & 239.24 & 438.93 & 49.60 & 400.16 & 551.44 & 387.96 & 22.99 & 347.70 & 409.92 \\
\hline Percent sodium & 34.36 & 4.82 & 30.56 & 41.67 & 39.52 & 1.77 & 37.67 & 42.39 & 40.89 & 1.50 & 38.80 & 43.47 \\
\hline SAR & 1.61 & 0.19 & 1.44 & 1.94 & 2.06 & 0.18 & 1.85 & 2.34 & 2.00 & 0.08 & 1.86 & 2.12 \\
\hline RSC & 0.20 & 0.47 & -0.41 & 0.86 & 4.41 & 0.77 & 3.74 & 6.09 & 3.91 & 0.31 & 3.31 & 4.28 \\
\hline WQI & 50.34 & 6.38 & 41.66 & 57.46 & 63.38 & 3.56 & 56.85 & 67.59 & 56.54 & 2.98 & 52.65 & 63.21 \\
\hline
\end{tabular}

DO levels in lakes vary according to their trophic levels, and depletion of DO in water probably is the most frequent result of water pollution (Srivastava et al. 2009). Dissolved oxygen is the maximum concentration of oxygen that can dissolve in water. As a function of water temperature, it may vary from place to place and time to time. DO is an important parameter to assess the waste assimilative capacity of the waters (Rao and Rao 2010). It fluctuate seasonally, daily and with variation in water temperature (Rao and Rao 2010; Wavde and Arjun 2010), mainly due to consumption of DO owing to respiration by aquatic animals, decomposition of organic matter, and various chemical reactions. The mean DO concentration in Sankey tank water ranged between $7.83 \pm 1.11 \mathrm{mg} / \mathrm{L}$ (March 2012), $7.70 \pm 1.16 \mathrm{mg} / \mathrm{L}$ (April 2012) and $6.28 \pm 0.42 \mathrm{mg} / \mathrm{L}$ (May 2012) while in Mallathahalli lake water, it was
$9.26 \pm 0.53 \mathrm{mg} / \mathrm{L}$ (March 2012), $8.88 \pm 0.39 \mathrm{mg} / \mathrm{L}$ (April 2012) and $7.54 \pm 0.76 \mathrm{mg} / \mathrm{L}$ (May 2012). As per USPH, the DO should be between 4 and $6 \mathrm{mg} / \mathrm{L}$ (De 2003) and if DO levels in water drop below $5.0 \mathrm{mg} / \mathrm{L}$, many life forms are put under stress (Raveen and Daniel 2010). The mean DO values in Sankey tank and Mallathahalli lake water was above the desirable limit of $6 \mathrm{mg} / \mathrm{L}$.

The average colour of Sankey tank water was $8.89 \pm$ 2.20 hazens (March 2012), $10.0 \pm 0.0$ hazens (April 2012) and $10.0 \pm 0.0$ hazens (May 2012) while in Mallathahalli lake water, it was $13.33 \pm 5.0$ hazens (March 2012), $15.0 \pm 7.50$ hazens (April 2012) and $20.0 \pm 0.0$ hazens (May 2012). The colour of Mallathahalli lake and Sankey tank water were below the permissible limit of 25 hazens (BIS 1998), though colour of Sankey tank was close to the limit. 
Table 4 Analytical results of Mallathahalli lake water from March 2012 to May 2012

\begin{tabular}{|c|c|c|c|c|c|c|c|c|c|c|c|c|}
\hline \multirow[t]{2}{*}{ Parameters } & \multicolumn{4}{|c|}{ March 2012} & \multicolumn{4}{|c|}{ April 2012} & \multicolumn{4}{|c|}{ May 2012} \\
\hline & Mean & SD & Min & Max & Mean & SD & Min & Max & Mean & SD & Min & Max \\
\hline DO & 9.26 & 0.53 & 8.85 & 10.38 & 8.88 & 0.39 & 8.32 & 9.51 & 7.54 & 0.76 & 6.50 & 8.50 \\
\hline $\mathrm{pH}$ & 8.65 & 0.34 & 8.12 & 9.10 & 8.78 & 0.73 & 7.50 & 9.51 & 8.94 & 0.53 & 8.10 & 9.60 \\
\hline $\mathrm{EC}$ & 1762.56 & 79.20 & 1612.00 & 1870.00 & 1777.89 & 32.62 & 1712.00 & 1812.00 & 1853.33 & 66.56 & 1792.00 & 2000.00 \\
\hline TDS & 1092.78 & 49.10 & 999.44 & 1159.40 & 1102.29 & 20.23 & 1061.44 & 1123.44 & 1149.07 & 41.27 & 1111.04 & 1240.00 \\
\hline Colour & 13.33 & 5.00 & 10.00 & 20.00 & 15.00 & 7.50 & 5.00 & 20.00 & 20.00 & 0.00 & 20.00 & 20.00 \\
\hline Turbidity & 1.00 & 0.00 & 1.00 & 1.00 & 5.00 & 0.00 & 5.00 & 5.00 & 5.00 & 0.00 & 5.00 & 5.00 \\
\hline BOD & 8.32 & 0.85 & 6.51 & 9.38 & 7.58 & 0.70 & 6.25 & 8.50 & 8.84 & 0.48 & 8.30 & 9.40 \\
\hline COD & 153.78 & 27.40 & 123.00 & 195.00 & 40.70 & 2.63 & 36.21 & 44.21 & 40.48 & 2.04 & 37.50 & 43.20 \\
\hline Temp & 28.72 & 0.97 & 28.00 & 30.20 & 29.98 & 0.83 & 28.50 & 31.20 & 30.59 & 0.37 & 30.00 & 31.10 \\
\hline $\mathrm{CO}_{2}$ & 6.11 & 0.58 & 5.20 & 7.20 & 7.98 & 1.21 & 6.20 & 9.50 & 6.51 & 0.93 & 5.10 & 7.70 \\
\hline TA & 655.89 & 211.03 & 400.00 & 920.00 & 736.67 & 48.33 & 648.00 & 801.00 & 556.22 & 53.44 & 480.00 & 605.00 \\
\hline TH & 517.22 & 75.52 & 420.00 & 612.00 & 553.00 & 32.02 & 512.00 & 592.00 & 429.22 & 62.41 & 355.00 & 508.00 \\
\hline $\mathrm{CaH}$ & 403.44 & 55.86 & 316.00 & 488.00 & 366.08 & 17.36 & 330.50 & 388.00 & 330.56 & 17.53 & 300.00 & 350.00 \\
\hline $\mathrm{Ca}^{2+}$ & 161.38 & 22.34 & 126.40 & 195.20 & 146.43 & 6.95 & 132.20 & 155.20 & 132.22 & 7.01 & 120.00 & 140.00 \\
\hline $\mathrm{MgH}$ & 113.78 & 49.50 & 51.00 & 164.50 & 186.92 & 37.90 & 137.50 & 261.50 & 98.67 & 74.03 & 7.00 & 175.00 \\
\hline $\mathrm{Mg}^{2+}$ & 27.76 & 12.08 & 12.44 & 40.14 & 45.61 & 9.25 & 33.55 & 63.81 & 24.07 & 18.06 & 1.71 & 42.70 \\
\hline $\mathrm{Cl}^{-}$ & 240.22 & 21.17 & 200.00 & 265.00 & 380.77 & 40.88 & 339.00 & 469.04 & 295.22 & 55.67 & 221.00 & 356.00 \\
\hline $\mathrm{NO}_{3}{ }^{-}$ & 17.72 & 2.99 & 10.01 & 19.81 & 33.09 & 4.92 & 27.39 & 40.21 & 30.39 & 1.73 & 28.40 & 33.50 \\
\hline $\mathrm{PO}_{4}{ }^{3-}$ & 14.35 & 4.26 & 8.50 & 18.90 & 37.64 & 2.97 & 32.66 & 41.00 & 40.91 & 2.56 & 36.50 & 45.60 \\
\hline $\mathrm{SO}_{4}{ }^{2-}$ & 41.60 & 9.52 & 28.80 & 56.31 & 90.24 & 10.01 & 75.39 & 102.00 & 88.90 & 4.33 & 81.40 & 95.40 \\
\hline $\mathrm{F}^{+}$ & 0.57 & 0.12 & 0.40 & 0.80 & 0.73 & 0.13 & 0.50 & 0.90 & 0.79 & 0.15 & 0.50 & 1.00 \\
\hline $\mathrm{K}^{+}$ & 22.00 & 1.79 & 12.40 & 30.10 & 40.24 & 0.22 & 38.60 & 43.00 & 37.20 & 0.26 & 31.50 & 41.00 \\
\hline $\mathrm{Na}^{+}$ & 178.56 & 37.35 & 120.00 & 231.00 & 159.67 & 27.14 & 123.00 & 191.00 & 138.56 & 28.03 & 100.00 & 172.00 \\
\hline $\mathrm{SiO}_{2}$ & 15.77 & 0.48 & 14.80 & 16.40 & 16.91 & 0.52 & 16.20 & 17.80 & 18.26 & 0.38 & 17.50 & 18.70 \\
\hline $\mathrm{Fe}^{2+}$ & 0.14 & 0.02 & 0.11 & 0.18 & 0.26 & 0.03 & 0.20 & 0.30 & 0.32 & 0.03 & 0.29 & 0.38 \\
\hline $\mathrm{HCO}_{3}{ }^{-}$ & 800.18 & 257.46 & 488.00 & 1122.40 & 898.73 & 58.96 & 790.56 & 977.22 & 678.59 & 65.19 & 585.60 & 738.10 \\
\hline Percent sodium & 41.38 & 5.06 & 30.95 & 45.70 & 36.31 & 4.24 & 29.69 & 41.18 & 38.53 & 1.76 & 35.49 & 41.01 \\
\hline SAR & 3.42 & 0.63 & 2.23 & 4.13 & 2.96 & 0.50 & 2.22 & 3.50 & 2.89 & 0.39 & 2.31 & 3.38 \\
\hline RSC & 2.78 & 5.68 & -4.23 & 10.01 & 3.67 & 0.76 & 2.70 & 5.16 & 2.54 & 0.52 & 1.90 & 3.65 \\
\hline WQI & 111.69 & 4.61 & 105.41 & 118.09 & 137.09 & 6.01 & 126.98 & 146.03 & 122.38 & 9.78 & 109.08 & 133.38 \\
\hline
\end{tabular}

Table 5 Classification of irrigation water based on electrical conductivity

\begin{tabular}{lll}
\hline $\begin{array}{l}\text { Sl. } \\
\text { No }\end{array}$ & Type of water & Suitability for irrigation \\
\hline 1 & $\begin{array}{c}\text { Low salinity water }(\mathrm{C} 1) \text { conductivity } \\
\text { between } 100 \text { and } 250 \mu \mathrm{S} / \mathrm{cm}\end{array}$ & $\begin{array}{c}\text { Suitable for all types of crops and all kinds of soil. } \\
\text { Permissible under normal irrigation practices except } \\
\text { in soils of extremely low permeability }\end{array}$ \\
2 & $\begin{array}{c}\text { Medium salinity water }(\mathrm{C} 2) \text { conductivity } \\
\text { between } 250 \text { and } 750 \mu \mathrm{S} / \mathrm{cm}\end{array}$ & $\begin{array}{c}\text { Can be used, if a moderate amount of leaching occurs. } \\
\text { Normal salt tolerant plants can be grown without } \\
\text { much salinity control }\end{array}$ \\
3 & $\begin{array}{c}\text { High salinity water }(\mathrm{C} 3) \text { conductivity } \\
\text { between } 750 \text { and } 2,250 \mu \mathrm{S} / \mathrm{cm}\end{array}$ & $\begin{array}{c}\text { Unsuitable for soil with restricted drainage. Only high- } \\
\text { salt tolerant plants can be grown }\end{array}$ \\
4 & $\begin{array}{c}\text { Very high salinity }(\mathrm{C} 4) \text { conductivity more } \\
\text { than } 2,250 \mu \mathrm{S} / \mathrm{cm}\end{array}$ & $\begin{array}{c}\text { Unsuitable for irrigation } \\
\end{array}$
\end{tabular}

Turbidity depends on the nature of the water bodies such as river under flood conditions, lake or other water existing under relatively quiescent conditions, wherein, most of the turbidity is due to colloidal and extremely fine dispersions.
The mean turbidity of Sankey tank water was $0.90 \pm 0.30$ NTU (March 2012), $1.0 \pm 0.0$ NTU (April 2012) and $1.0 \pm 0.0$ NTU (May 2012) while in Mallathahalli lake water, it was $1.0 \pm 0.0 \mathrm{NTU}$ (March 2012), $5.0 \pm 0.0$ 
NTU (April 2012) and $5.0 \pm 0.0$ NTU (May 2012). The turbid nature of Sankey tank and Mallathahalli lake water was well below the permissible limit of 10 NTU.

The average temperature of Sankey tank water was $28.19 \pm 0.4{ }^{\circ} \mathrm{C}$ (March 2012), $30.04 \pm 0.5{ }^{\circ} \mathrm{C}$ (April 2012) and $30.13 \pm 0.39{ }^{\circ} \mathrm{C}$ (May 2012) while in Mallathahalli lake water, it was $28.72 \pm 0.97{ }^{\circ} \mathrm{C}$ (March 2012), $29.98 \pm$ $0.83{ }^{\circ} \mathrm{C}$ (April 2012) and $30.59 \pm 0.37{ }^{\circ} \mathrm{C}$ (May 2012).

BOD and COD are important parameters that indicate contamination with organic wastes (Siraj et al. 2010). Biochemical oxygen demand (BOD) is the amount of oxygen required by bacteria while stabilizing decomposable organic matter under aerobic conditions (Sawyer and McCarty 1978). It is required to assess the pollution of surface and ground water where contamination occurred due to disposal of domestic and industrial effluents. According to WHO drinking water standard, BOD should not exceed $6 \mathrm{mg} / \mathrm{L}$ (De 2003). BOD values in Sankey tank water ranged from $8.05 \pm 1.18 \mathrm{mg} / \mathrm{L}$ (March 2012), $5.78 \pm 0.58 \mathrm{mg} / \mathrm{L}$ (April 2012) and $5.87 \pm 0.57 \mathrm{mg} / \mathrm{L}$ (May 2012) while in Mallathahalli lake water, it was $8.32 \pm 0.85 \mathrm{mg} / \mathrm{L}$ (March 2012), $7.58 \pm 0.70 \mathrm{mg} / \mathrm{L}$ (April 2012) and $8.84 \pm 0.48 \mathrm{mg} / \mathrm{L}$ (May 2012). It is evident from the results that BOD values of both the lakes were well above the standard limit of $3 \mathrm{mg} / \mathrm{L}$.

Chemical oxygen demand (COD) determines the oxygen required for chemical oxidation of most organic matter and oxidizable inorganic substances with the help of strong chemical oxidant. In conjunction with the BOD, the COD test is helpful in indicating toxic conditions and the presence of biologically resistant organic substances (Sawyer and McCarty 1978). COD values in Sankey tank water was $71.44 \pm 12.32 \mathrm{mg} / \mathrm{L}$ (March 2012), $37.94 \pm 1.41 \mathrm{mg} / \mathrm{L}$ (April 2012) and $21.91 \pm 3.19 \mathrm{mg} / \mathrm{L}$ (May 2012). In Mallathahalli lake water, it was $153.78 \pm 27.40 \mathrm{mg} / \mathrm{L}$ (March 2012), $40.70 \pm 2.63 \mathrm{mg} / \mathrm{L}$ (April 2012) and $40.48 \pm$ $2.04 \mathrm{mg} / \mathrm{L}$ (May 2012). Khuhawari et al. (2009) associated higher values of COD with increased anthropogenic pressures on lakes and it is evident from the results that COD values of both the lakes were very high, an indication of flooded organic matter.

Alkalinity is a measure of the ability of water to neutralize acids. It is due to the presence of bicarbonates, carbonates and hydroxide of calcium, magnesium, sodium, potassium and salts of weak acids and strong bases as borates, silicates, phosphates, etc. Large amount of alkalinity imparts a bitter taste, harmful for irrigation as it damages soil and hence reduces crop yields (Sundar and Saseetharan 2008). In Sankey tank water, the total alkalinity values was $158.98 \pm 20.64 \mathrm{mg} / \mathrm{L}$ (March 2012), $358.78 \pm$ $40.65 \mathrm{mg} / \mathrm{L}$ (April 2012) and $318.00 \pm 18.85 \mathrm{mg} / \mathrm{L}$ (May 2012) and in Mallathahalli lake water, it was $655.89 \pm$ 211.03 mg/L (March 2012), $736.67 \pm 48.33$ mg/L (April
2012) and 556.22 $\pm 53.44 \mathrm{mg} / \mathrm{L}$ (May 2012). It is evident that alkalinity values in Sankey tank water were above the permissible limit of $600 \mathrm{mg} / \mathrm{L}$ (BIS 1998) during April and May 2012. In contrast, Mallathahalli lake water showed alkalinity value higher than the desirable limit for all the months.

Total hardness values was $148.90 \pm 14.18 \mathrm{mg} / \mathrm{L}$ (March 2012), $138.93 \pm 5.59 \mathrm{mg} / \mathrm{L}$ (April 2012) and $122.14 \pm$ $5.09 \mathrm{mg} / \mathrm{L}$ (May 2012) and in Mallathahalli lake water, it was $517.22 \pm 75.52 \mathrm{mg} / \mathrm{L} \quad$ (March 2012), $553.00 \pm$ $3 ! 2.02 \mathrm{mg} / \mathrm{L}$ (April 2012) and $429.22 \pm 62.41 \mathrm{mg} / \mathrm{L}$ (May 2012). Total hardness values in Sankey tank and Mallathahalli lake water was below the permissible limit of $600 \mathrm{mg} / \mathrm{L}$ (BIS 1998). The degree of hardness of drinking water has been classified (WHO 2004) in terms of its equivalent $\mathrm{CaCO}_{3}$ concentration (Table 6) and accordingly, both Sankey tank and Mallathahalli lake water respectively, belong to hard and very hard category (Sawyer and McCarthy 1967).

In Sankey tank, the calcium hardness values of $92.32 \pm$ $1.37 \mathrm{mg} / \mathrm{L}$ (March 2012), $57.62 \pm 6.05 \mathrm{mg} / \mathrm{L}$ (April 2012) and $38.33 \pm 5.73 \mathrm{mg} / \mathrm{L}$ (May 2012), were well below the permissible limit of $200 \mathrm{mg} / \mathrm{L}$ (BIS 1998) except for March 2012. In Mallathahalli lake water, it was $403.44 \pm$ 55.86 mg/L (March 2012), $366.08 \pm 17.36$ mg/L (April 2012) and $330.56 \pm 17.53 \mathrm{mg} / \mathrm{L}$ (May 2012), which were very high compared to their permissible limit.

The magnesium hardness in Sankey tank water was $56.58 \pm 14.33 \mathrm{mg} / \mathrm{L}$ (March 2012), $81.31 \pm 9.16 \mathrm{mg} / \mathrm{L}$ (April 2012) and $83.81 \pm 3.92 \mathrm{mg} / \mathrm{L}$ (May 2012), while in Mallathahalli lake water, it was $113.78 \pm 49.50 \mathrm{mg} / \mathrm{L}$ (March 2012), $186.92 \pm 37.90 \mathrm{mg} / \mathrm{L}$ (April 2012) and $98.67 \pm 74.03 \mathrm{mg} / \mathrm{L}$ (May 2012).

The dissolved $\mathrm{CO}_{2}$ in Sankey tank water was $7.29 \pm$ $0.64 \mathrm{mg} / \mathrm{L}$ (March 2012), $7.50 \pm 0.60 \mathrm{mg} / \mathrm{L}$ (April 2012) and $5.99 \pm 0.34 \mathrm{mg} / \mathrm{L}$ (May 2012), while in Mallathahalli lake water, it was $6.11 \pm 0.58 \mathrm{mg} / \mathrm{L}$ (March 2012), $7.98 \pm 1.21 \mathrm{mg} / \mathrm{L}$ (April 2012) and $6.51 \pm 0.93 \mathrm{mg} / \mathrm{L}$ (May 2012). Similarly, the mean concentration of silica in Sankey tank water was $11.38 \pm 0.77 \mathrm{mg} / \mathrm{L}$ (March 2012), $11.99 \pm 0.44 \mathrm{mg} / \mathrm{L}$ (April 2012) and $10.39 \pm 0.61 \mathrm{mg} / \mathrm{L}$ (May 2012), while in Mallathahalli lake water, it was $15.77 \pm 0.48 \mathrm{mg} / \mathrm{L} \quad($ March 2012), $16.91 \pm 0.52 \mathrm{mg} / \mathrm{L}$ (April 2012) and $18.26 \pm 0.38 \mathrm{mg} / \mathrm{L}$ (May 2012). It is

Table 6 Classification of water depending upon the hardness (WHO 2004)

\begin{tabular}{|c|c|}
\hline Classification & Hardness range $(\mathrm{mg} / \mathrm{L})$ \\
\hline Soft & $0-75$ \\
\hline Medium hard & $75-150$ \\
\hline Hard & $150-300$ \\
\hline Very hard & Above 300 \\
\hline
\end{tabular}


evident that Mallathahalli lake water showed higher concentration of silica, might be due to accumulation of more of sediment/silt in comparison with Sankey tank.

\section{Major Ion Chemistry}

In Mallathahalli lake water, the predominant cation trend was in the order of $\mathrm{Ca}^{2+}>\mathrm{Na}^{+}>\mathrm{Mg}^{2+}>\mathrm{K}^{+}$with calcium being dominant cation and the predominant anion trend was in the order of $\mathrm{HCO}_{3}{ }^{-}>\mathrm{Cl}^{-}>\mathrm{SO}_{4}{ }^{2-}$, with bicarbonate being the dominant anion (Fig. 2). Contrast to this, in Sankey tank water, the predominant cation trend was in the order $\mathrm{Na}^{+}>\mathrm{Mg}^{2+}>\mathrm{Ca}^{2+}>\mathrm{K}^{+}$with sodium being dominant cation and the predominant anion trend was $\mathrm{HCO}_{3}{ }^{-}>\mathrm{Cl}^{-}>\mathrm{SO}_{4}{ }^{2-}$, with bicarbonate being the dominant anion (Fig. 2). Spatial trend of water composition (viz., major anions and cations) in Sankey tank and Mallathahalli lake are presented by Figs. 3 and 4 .

\section{Chemistry of cations}

The mean concentration of calcium in Sankey tank water was $36.93 \pm 0.55 \mathrm{mg} / \mathrm{L} \quad$ (March 2012), $23.05 \pm 2.42 \mathrm{mg} / \mathrm{L}$ (April 2012) and $15.33 \pm 2.29 \mathrm{mg} / \mathrm{L}$ (May 2012), while in Mallathahalli lake water, it was $161.38 \pm 22.34 \mathrm{mg} / \mathrm{L}$ (March 2012), $146.43 \pm 6.95 \mathrm{mg} / \mathrm{L}$ (April 2012) and $132.22 \pm 7.01 \mathrm{mg} / \mathrm{L}$ (May 2012). It is apparent that Mallathahalli lake water showed higher calcium content compared to Sankey tank water. However, calcium content in both the lake water was below the permissible limit of $200 \mathrm{mg} / \mathrm{L}$.

The average magnesium values in Sankey tank water was $13.80 \pm 3.50 \mathrm{mg} / \mathrm{L} \quad($ March 2012), $19.84 \pm 2.24 \mathrm{mg} / \mathrm{L}$
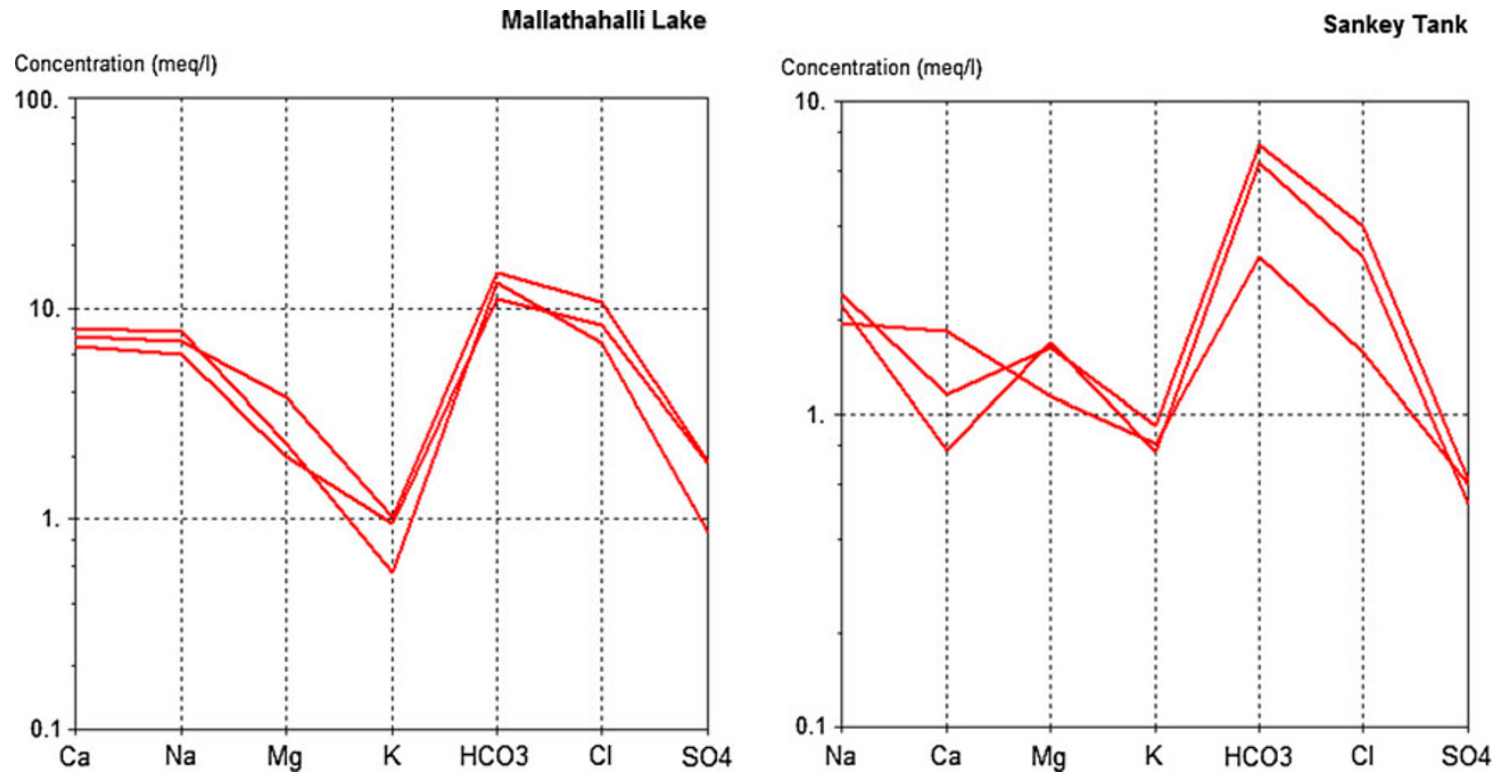

Fig. 2 Schoeller diagrams illustrating major ionic dominance in the surface water of Mallathahalli lake and Sankey tank
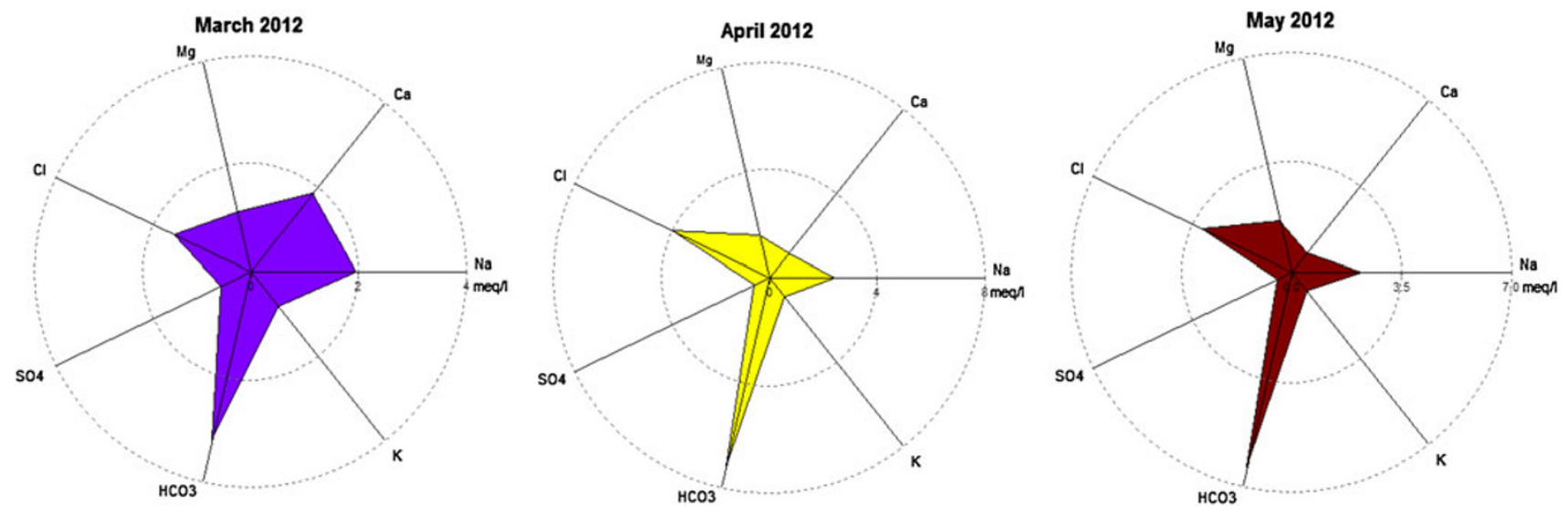

Fig. 3 Radial diagram showing spatial trend in water composition (viz., major anions and cations) of Sankey tank water 

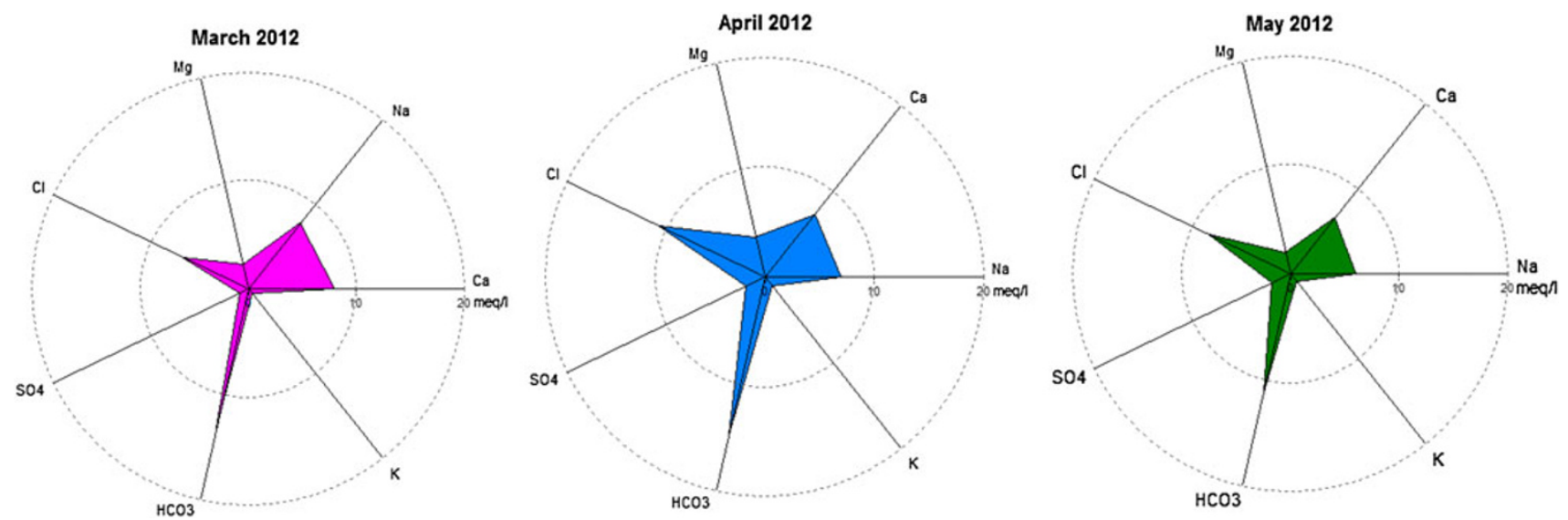

Fig. 4 Radial diagram showing spatial trend in water composition (viz., major anions and cations) of Mallathahalli lake water

(April 2012) and $20.45 \pm 0.96 \mathrm{mg} / \mathrm{L}$ (May 2012), while in Mallathahalli lake water, it was $27.76 \pm 12.08 \mathrm{mg} / \mathrm{L}$ (March 2012), $45.61 \pm 9.25 \mathrm{mg} / \mathrm{L}$ (April 2012) and $24.07 \pm 18.06 \mathrm{mg} / \mathrm{L}$ (May 2012). It is evident that Sankey tank and Mallathahalli lake water had magnesium concentration within the permissible limit of $100 \mathrm{mg} / \mathrm{L}$.

The mean sodium concentration in Sankey tank water was $45.01 \pm 3.58 \mathrm{mg} / \mathrm{L}$ (March 2012), $55.79 \pm 5.07 \mathrm{mg} / \mathrm{L}$ (April 2012) and $50.93 \pm 1.78 \mathrm{mg} / \mathrm{L}$ (May 2012). The mean sodium value in Mallathahalli lake water was $178.56 \pm 37.35 \mathrm{mg} / \mathrm{L}$ (March 2012), $159.67 \pm 27.14 \mathrm{mg} / \mathrm{L}$ (April 2012) and $138.56 \pm 28.03 \mathrm{mg} / \mathrm{L}$ (May 2012). It is evident that Sankey tank and Mallathahalli lake water showed sodium values within the permissible limit of $200 \mathrm{mg} / \mathrm{L}$. The average potassium concentration in Sankey tank water was $31.59 \pm 1.73 \mathrm{mg} / \mathrm{L}$ (March 2012), $36.01 \pm$ $0.31 \mathrm{mg} / \mathrm{L}$ (April 2012) and $29.58 \pm 1.95 \mathrm{mg} / \mathrm{L}$ (May 2012). The mean potassium value in Mallathahalli lake water was $22.0 \pm 1.79 \mathrm{mg} / \mathrm{L}$ (March 2012), $40.24 \pm$ $0.22 \mathrm{mg} / \mathrm{L}$ (April 2012) and $37.2 \pm 0.26 \mathrm{mg} / \mathrm{L}$ (May 2012). Both Sankey tank and Mallathahalli lake water showed very high potassium content compared to the permissible limit of $10 \mathrm{mg} / \mathrm{L}$ (BIS 1998), favouring the fact that both lakes were eutrophic in condition and higher content of sodium and potassium in freshwaters is due to domestic sewage contamination (Bhat et al. 2001).

The mean ferrous iron $\left(\mathrm{Fe}^{2+}\right)$ values in Sankey tank water was $0.12 \pm 0.01 \mathrm{mg} / \mathrm{L}$ (March 2012), $0.17 \pm$ $0.06 \mathrm{mg} / \mathrm{L}$ (April 2012) and $0.16 \pm 0.05 \mathrm{mg} / \mathrm{L}$ (May 2012). The mean ferrous iron values in Mallathahalli lake water was $0.14 \pm 0.02 \mathrm{mg} / \mathrm{L}$ (March 2012), $0.26 \pm$ $0.03 \mathrm{mg} / \mathrm{L}$ (April 2012) and $0.32 \pm 0.03 \mathrm{mg} / \mathrm{L}$ (May 2012). Both Sankey tank and Mallathahalli lake water showed mean ferrous iron concentration below the permissible limit of $1.0 \mathrm{mg} / \mathrm{L}$ (BIS 1998) except for Mallathahalli lake water during April 2012.
Chemistry of anions

The mean bicarbonate values in Sankey tank water was $193.95 \pm 25.18 \mathrm{mg} / \mathrm{L}$ (March 2012), $438.93 \pm 49.60 \mathrm{mg} / \mathrm{L}$ (April 2012) and $387.96 \pm 22.99 \mathrm{mg} / \mathrm{L}$ (May 2012). In Mallathahalli lake water, it was $800.18 \pm 257.46 \mathrm{mg} / \mathrm{L}$ (March 2012), $898.73 \pm 58.96 \mathrm{mg} / \mathrm{L}$ (April 2012) and $678.59 \pm 65.19 \mathrm{mg} / \mathrm{L}$ (May 2012). The Mallathahalli lake water showed higher bicarbonate values compared to Sankey tank water.

The average chloride concentration in Sankey tank water was $55.86 \pm 12.53 \mathrm{mg} / \mathrm{L}$ (March 2012), $141.66 \pm 9.44$ $\mathrm{mg} / \mathrm{L}$ (April 2012) and $112.39 \pm 6.12 \mathrm{mg} / \mathrm{L}$ (May 2012). In Mallathahalli lake water, it was $240.22 \pm 21.17 \mathrm{mg} / \mathrm{L}$ (March 2012), $380.77 \pm 40.88 \mathrm{mg} / \mathrm{L}$ (April 2012) and $295.22 \pm 55.67 \mathrm{mg} / \mathrm{L}$ (May 2012). The Mallathahalli lake water showed higher chloride values compared to Sankey tank water, but both the lake water had chloride values well below the permissible limit of 1,000 mg/L.

The mean sulphate concentration in Sankey tank water was $28.83 \pm 3.70 \mathrm{mg} / \mathrm{L}$ (March 2012), $29.69 \pm 2.84 \mathrm{mg} / \mathrm{L}$ (April 2012) and $25.03 \pm 1.95 \mathrm{mg} / \mathrm{L}$ (May 2012). In Mallathahalli lake water, it was $41.60 \pm 9.52 \mathrm{mg} / \mathrm{L}$ (March 2012), $90.24 \pm 10.01 \mathrm{mg} / \mathrm{L}$ (April 2012) and $88.90 \pm 4.33 \mathrm{mg} / \mathrm{L}$ (May 2012). Both Sankey tank and Mallathahalli lake water showed sulphate values below the permissible limit of $400 \mathrm{mg} / \mathrm{L}$.

Nitrate concentration in groundwater and surface water is normally low but can reach high levels as a result of agricultural runoff, refuge dump runoffs, or contamination with human or animal wastes (Nas and Berktay 2006). The mean nitrate concentration in Sankey tank water was $5.04 \pm$ $0.43 \mathrm{mg} / \mathrm{L}$ (March 2012), $18.20 \pm 3.44 \mathrm{mg} / \mathrm{L}$ (April 2012) and $20.23 \pm 4.46 \mathrm{mg} / \mathrm{L}$ (May 2012). In Mallathahalli lake water, it was $17.72 \pm 2.99 \mathrm{mg} / \mathrm{L}$ (March 2012), $33.09 \pm$ $4.92 \mathrm{mg} / \mathrm{L}$ (April 2012) and $30.39 \pm 1.73 \mathrm{mg} / \mathrm{L}$ (May 2012). 
Table 7 Classification of irrigation water based on SAR

\begin{tabular}{|c|c|c|c|}
\hline $\begin{array}{l}\text { Sl. } \\
\text { No }\end{array}$ & Types of water and SAR value & Quality & Suitability for irrigation \\
\hline 1 & $\begin{array}{l}\text { Low sodium water (S1) SAR } \\
\text { value: } 0-10\end{array}$ & Excellent & $\begin{array}{l}\text { Suitable for all types of crops and all types of soils, } \\
\text { except for those crops, which are sensitive to sodium }\end{array}$ \\
\hline 2 & $\begin{array}{l}\text { Medium sodium water }(\mathrm{S} 2) \\
\text { SAR value: } 10-18\end{array}$ & Good & $\begin{array}{l}\text { Suitable for coarse textured or organic soil with good } \\
\text { permeability. Relatively unsuitable in fine textured } \\
\text { soils }\end{array}$ \\
\hline 3 & $\begin{array}{l}\text { High sodium water }(\mathrm{S} 3) \mathrm{SAR} \\
\text { value: } 18-26\end{array}$ & Fair & $\begin{array}{l}\text { Harmful for almost all types of soil; Requires good } \\
\text { drainage, high leaching gypsum addition }\end{array}$ \\
\hline 4 & $\begin{array}{l}\text { Very high sodium water (S4) } \\
\text { SAR value: above } 26\end{array}$ & Poor & Unsuitable for irrigation \\
\hline
\end{tabular}

Both Sankey tank and Mallathahalli lake water showed nitrate values below the permissible limit of $45 \mathrm{mg} / \mathrm{L}$.

The mean phosphate values in Sankey tank water was $8.86 \pm 0.46 \mathrm{mg} / \mathrm{L}$ (March 2012), $9.59 \pm 0.97 \mathrm{mg} / \mathrm{L}$ (April 2012) and $9.48 \pm 1.51 \mathrm{mg} / \mathrm{L}$ (May 2012). In Mallathahalli lake water, it was $14.35 \pm 4.26 \mathrm{mg} / \mathrm{L}$ (March 2012), $37.64 \pm 2.97 \mathrm{mg} / \mathrm{L}$ (April 2012) and $40.91 \pm 2.56 \mathrm{mg} / \mathrm{L}$ (May 2012). Both Sankey tank and Mallathahalli lake water showed high phosphate concentration compared to the permissible limit of $0.3 \mathrm{mg} / \mathrm{L}$, illustrating the existence of eutrophic condition in both the lakes. $\mathrm{PO}_{4}{ }^{3-}$ enters the lakes through domestic wastewater, accounting for the accelerated eutrophication (Vyas et al. 2006) and the augmented concentration of $\mathrm{PO}_{4}{ }^{3-}$ and $\mathrm{NO}_{3}-\mathrm{N}$ in lakes resulted in enhanced phytoplankton productivity (Pandit and Yousuf 2002).

The mean fluoride concentration in Sankey tank water was $0.32 \pm 0.07 \mathrm{mg} / \mathrm{L}$ (March 2012), $0.42 \pm 0.22 \mathrm{mg} / \mathrm{L}$ (April 2012) and $0.47 \pm 0.21 \mathrm{mg} / \mathrm{L}$ (May 2012). In Mallathahalli lake water, it was $0.57 \pm 0.12 \mathrm{mg} / \mathrm{L}$ (March 2012), $\quad 0.73 \pm 0.13 \mathrm{mg} / \mathrm{L} \quad$ (April 2012) and $0.79 \pm$ $0.15 \mathrm{mg} / \mathrm{L}$ (May 2012). Both Sankey tank and Mallathahalli lake water showed fluoride concentration well below the permissible limit of $1.5 \mathrm{mg} / \mathrm{L}$.

Irrigational quality parameters

\section{Sodium absorption ratio}

If the SAR ratio of the water samples in the study area is less than 10, it is excellent for irrigation purposes. The SAR values for each water sample was calculated using the following equation (Richards 1954).

$\mathrm{SAR}=\frac{\mathrm{Na}^{+}}{\sqrt{\frac{\left(\mathrm{Ca}^{2+}+\mathrm{Mg}^{2+}\right)}{2}}}$

The mean SAR concentration in Sankey tank water was $1.61 \pm 0.19$ (March 2012), $2.06 \pm 0.18$ (April 2012) and $2.00 \pm 0.08$ (May 2012). In Mallathahalli lake water, it was $3.42 \pm 0.63$ (March 2012), $2.96 \pm 0.50$ (April 2012) and $2.89 \pm 0.39$ (May 2012). According to classification given in Table 7, both Sankey tank and Mallathahalli lake water showed mean SAR value below 10, indicating that lake waters are excellent (S1) for irrigation.

\section{Residual sodium carbonate}

The sodium hazard also increases, if the water contains a high concentration of bicarbonate ion. As the soil solution becomes more concentrated, there is a tendency for calcium and magnesium to precipitate as carbonates thus, increasing the relative proportion of sodium as a consequence. RSC can be calculated using the equation below employing data of alkalinity, calcium and magnesium.

$\mathrm{RSC}=($ Alkalinity $\times 0.0333)-\left(\mathrm{Ca}_{\mathrm{meq}}^{\mathbf{2}+}+\mathbf{M g}_{\mathrm{meq}}^{2+}\right)$

where concentration of $\mathrm{Ca}^{2+}$ and $\mathrm{Mg}^{2+}$ are in meq/L and alkalinity values in $\mathrm{mg} / \mathrm{L}$. The mean RSC concentration in Sankey tank water was $0.20 \pm 0.47$ (March 2012), $4.41 \pm$ 0.77 (April 2012) and $3.91 \pm 0.31$ (May 2012). In Mallathahalli lake water, it was $2.78 \pm 5.68$ (March 2012), $3.67 \pm 0.76$ (April 2012) and $2.54 \pm 0.52$ (May 2012). Both Sankey tank and Mallathahalli lake water showed mean RSC value above 2.50, illustrating that these waters are unsuitable for irrigation (Table 8).

Percent sodium

It has been widely recommended that the percentage of sodium in irrigation water should not exceed 50-60, in order to avoid its deleterious effects on soil. When the percent sodium exceeds 60 , the water is considered to be unsuitable for irrigation purposes. It is considered, that water is of class I quality if the \% sodium is less than $30 \%$, class II quality if the $\%$ sodium is between 30 and 75 , and

Table 8 Water quality based on RSC (after Richards 1954)

\begin{tabular}{ll}
\hline RSC (epm) & Remark on quality \\
\hline$<1.25$ & Safe/good \\
$1.25-2.50$ & Marginal/doubtful \\
$>2.50$ & Unsuitable \\
\hline
\end{tabular}


Table 9 Sodium percent water class (Wilcox 1995)

\begin{tabular}{ll}
\hline Sodium $(\%)$ & Water class \\
\hline$<20$ & Excellent \\
$20-40$ & Good \\
$40-60$ & Permissible \\
$60-80$ & Doubtful \\
$>80$ & Unsuitable
\end{tabular}

of class III quality if it is more than 75 . Percent sodium can be determined using the following formula:

$\% \mathbf{N a}=\frac{\mathbf{N a}}{(\mathrm{Ca}+\mathrm{Mg}+\mathrm{K}+\mathrm{Na})} \times 100$

where the concentration of $\mathrm{Ca}^{2+}, \mathrm{Mg}^{2+}, \mathrm{Na}^{+}$and $\mathrm{K}^{+}$are expressed in milliequivalents per litre (epm or meq/L). Soil permeability has been found to be affected by high sodium ratio. Water quality reflected by sodium percentage values can be categorized as shown in Table 9 .

The mean percent sodium concentration in Sankey tank water was $34.36 \pm 4.82$ (March 2012), $39.52 \pm 1.77$ (April 2012) and $40.89 \pm 1.50$ (May 2012). In
Mallathahalli lake water, it was $41.38 \pm 5.06$ (March 2012), $36.31 \pm 4.24$ (April 2012) and $38.53 \pm 1.76$ (May 2012). Sankey tank water belongs to good category during March and April months and to permissible category during May 2012. In contrast, Mallathahalli lake water belongs to good category during April and May and to permissible category during March 2012 (Table 9).

Water quality index

The computed WQI values are classified into five types namely, excellent water (WQI $<50)$, good water $(50>$ $\mathrm{WQI}<100)$, poor water $(100>\mathrm{WQI}<200)$, very poor water $(200>\mathrm{WQI}<300)$ and water unsuitable for drinking (WQI > 300). In the present study, the computed WQI values in Sankey tank water was $50.34 \pm 6.38$ (March 2012), $63.38 \pm 3.56$ (April 2012) and $56.54 \pm 2.98$ (May 2012), while in Mallathahalli lake water, it was $111.69 \pm 4.61$ (March 2012), $137.09 \pm 6.01$ (April 2012) and 122.38 \pm 9.78 (May 2012). It is evident from the results that Sankey tank water fall under good water class while Mallathahalli lake water fall under poor water category (Fig. 5).

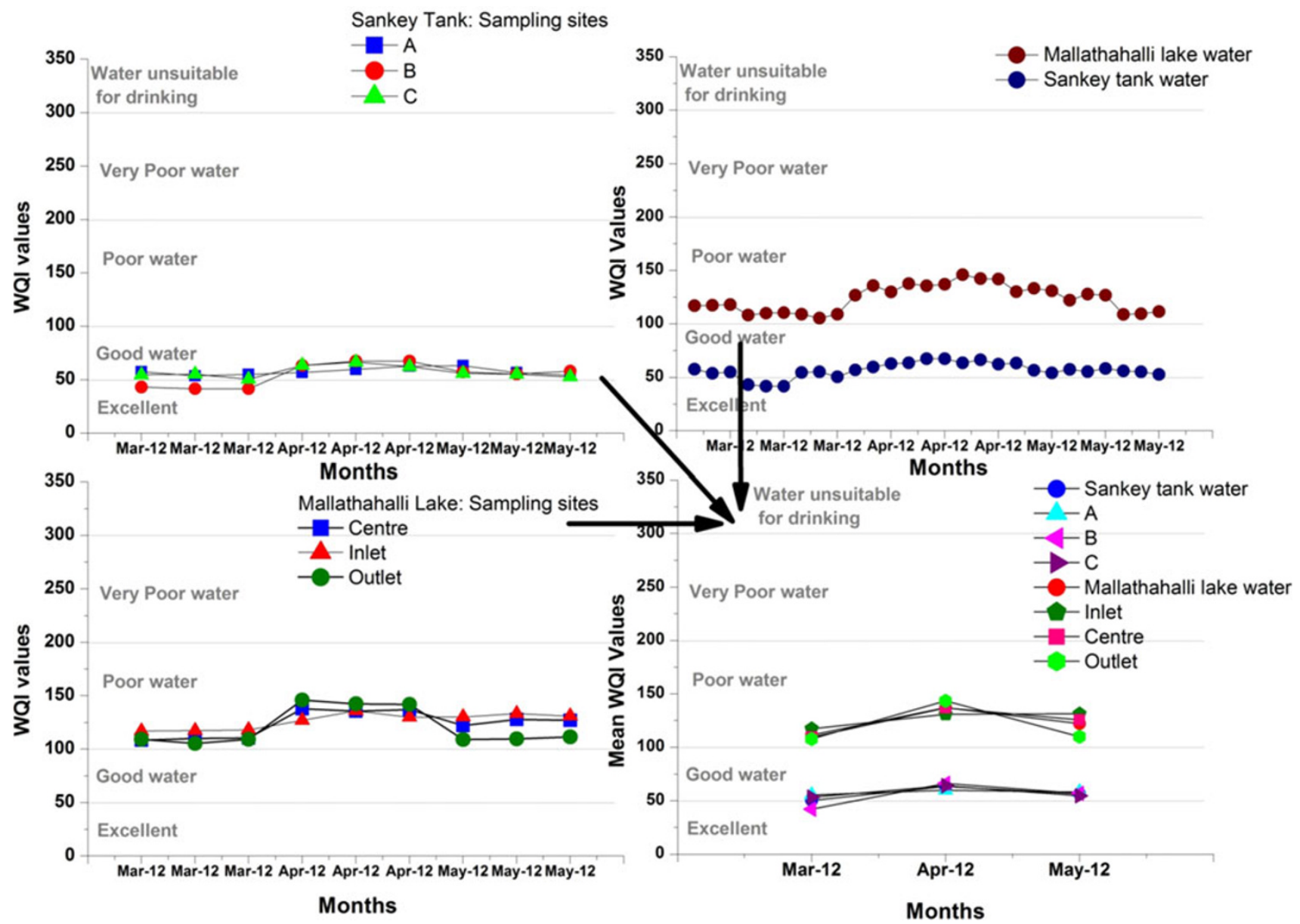

Fig. 5 Spatio-temporal variation in WQI for Sankey tank and Mallathahalli lake waters 


\section{Conclusion}

Water quality index technique used to assess the suitability of surface water Sankey tank and Mallathahalli lake for domestic and irrigation purposes illustrated that Sankey tank water belongs to good water class and Mallathahalli lake water to poor water category. The high WQI values in Mallathahalli lake water were mainly due to the presence of higher concentration of total dissolved solids, electrical conductivity, total alkalinity, potassium, total hardness, calcium and chloride in the surface water. Sankey tank and Mallathahalli lake water, respectively, were hard and very hard in nature. Electrical conductivity classified Sankey tank and Mallathahalli lake water, respectively, to medium (C2) and high (C3) salinity classes. Both the water bodies belong to excellent (S1) class based on SAR values, indicating their suitability for irrigation. Sankey tank water is C2S1 type while Mallathahalli lake water is C3S1 type based on correlation between SAR and electrical conductivity. On irrigating soil with this water, water gets evaporated leaving salts caked on the soil surface and finally may spoil the texture of soil. Soil with poor internal drainage facilities is another reason, mainly responsible for accumulation of salt in the root zone. Hence, the analysis revealed that the surface water of both the lakes needs some degree of treatment before usage and it is essential to protect them from the perils of contamination.

Open Access This article is distributed under the terms of the Creative Commons Attribution License which permits any use, distribution, and reproduction in any medium, provided the original author(s) and the source are credited.

\section{References}

American Public Health Association (APHA) (2005) Standard method for examination of water and wastewater, 21st edn. APHA, AWWA, WPCF, Washington

Benjamin R, Chakrapani BK, Devashish K, Nagarathna AV, Ramachandra TV (1996) Fish mortality in Bangalore Lakes, India. EGJ 1(6). http://escholarship.org/uc/item/00d1m13p

Bhat SA, Rather SA, Pandit AK (2001) Impact of effluent from SheriKashmir institute of medical sciences (SKIMS), Soura on Anchar Lake. J Res Dev 1:30-37

Bureau of Indian Standards (BIS) (1998) Drinking water specifications (revised 2003), IS: 10500

Choudhary P, Routh J, Chakrapani GJ (2010) Organic geochemical record of increased productivity in Lake Naukuchiyatal, Kumaun Himalayas, India. Environ Earth Sci 60:837-843. doi:10.1007/ s12665-009-0221-3

De AK (2003) Environmental chemistry, 5th edn. New Age International Publishers, New Delhi

Garg RK, Rao RJ, Uchchariya D, Shukla G, Saksena DN (2010) Seasonal variations in water quality and major threats to Ramsagar reservoir, India. Afr Environ Sci Technol 4(2):061-076

Gupta S, Maheto A, Roy P, Datta JK, Saha RN (2008) Geochemistry of groundwater Burdwan district, West Bengal India. Environ Geol 53:1271-1282. doi:10.1007/s00254-007-0725-7
Harilal CC, Hashim A, Arun PR, Baji S (2004) Hydro geochemistry of two rivers of Kerala with special reference to drinking water quality. J Ecol Environ Conserv 10(2):187-192

Iscen CF, Emiroglu O, Ilhan S, Arslan N, Yilmaz V, Ahiska S (2008) Application of multivariate statistical techniques in the assessment of surface water quality in Uluabat Lake, Turkey. Environ Monit Assess 144:269-276. doi:10.1007/s10661-007-9989-3

Khuhawari MY, Mirza MA, Leghari SM, Arain R (2009) Limnological study of Baghsar Lake district Bhimber, Azad Kashmir. Pak J Bot 41(4):1903-1915

Mishra PC, Patel RK (2001) Study of pollution load in the drinking water of Rairangpur: a small tribal dominated town of North Orissa. Indian J Environ Ecoplan 5(2):293-298

Naik S, Purohit KM (2001) Studies on water quality of river Brahmani in Sundargarh district, Orissa. Indian J Environ Ecoplan 5(2):397-402

Nas B, Berktay A (2006) Groundwater contamination by nitrates in the city of Konya, (Turkey): a GIS perspective. J Environ Manage 79:30-37

Oczkowski A, Nixon S (2008) Increasing nutrient concentrations and the rise and fall of a coastal fishery, a review of data from the Nile Delta, Egypt. Estuar Coast Shelf Sci 77:309-319. doi: 10.1016/j.ecss.2007.11.028

Pandit AK (2002) Topical evolution of lakes in Kashmir Himalaya. In: Pandit AK (ed) Natural resources of western Himalaya. Valley Book House, Srinagar J\&K, pp 213-242

Pandit AK, Yousuf AR (2002) Trophic status of Kashmir Himalayan lakes as depicted by water chemistry. J Res Dev 2:1-12

Papatheodorou G, Demopoulou G, Lambrakis N (2006) A long-term study of temporal hydrochemical data in a shallow lake using multivariate statistical techniques. Ecol Model 193:759-776

Prasanna MV, Chidambaram S, Gireesh TV, Ali TVJ (2010) A study on hydrochemical characteristics of surface and sub-surface water in and around Perumal Lake, Cuddalore district, Tamil Nadu, South India. Environ Earth Sci. doi:10.1007/s12665-010-0664-6

Purandara BK, Varadarajan N, Jayashree K (2003) Impact of sewage on ground water: a case study. Poll Res 22(2):189-197

Rao GS, Rao GN (2010) Study of groundwater quality in greater Visakhapatnam city, Andhra Pradesh (India). J Environ Sci Eng 52(2):137-146

Raveen R, Daniel M (2010) Spatial changes in water quality of urban lakes in Chennai (India) - a case study. J Environ Sci Eng 52(3):259-264

Ravikumar P, Venkatesharaju K, Prakash KL, Somashekar RK (2011) Geochemistry of groundwater and groundwater prospects evaluation, Anekal Taluk, Bangalore Urban District, Karnataka, India. Environ Monit Assess 179:93-112. doi:10.1007/ s10661-010-1721-z

Richards LA (U.S. Salinity Laboratory) (1954) Diagnosis and improvement of saline and alkaline soils, U.S. Department of Agriculture Hand Book

Sahu P, Sikdar PK (2008) Hydrochemical framework of the aquifer in and around East Kolkata wetlands, West Bengal. India Environ Geol 55:823-835

Sawyer GN, McCarthy DL (1967) Chemistry of sanitary engineers, 2nd edn. McGraw Hill, New York, p 518

Sawyer CN, McCarty PL (1978) Chemistry for environmental engineering, 3rd edn. McGraw-Hill Book Company, New York

Shuchun Y, Bin X, Deyang K (2010) Chronology and nutrients change in recent sediment of Taihu Lake, lower Changjiang River Basin, East China. Chin Geogr Sci 20(3):202-208

Singh DF (1992) Studies on the water quality index of some major rivers of Pune. Maharashtra. Proc Acad Environ Biol. 1(1):61-66

Siraj S, Yousuf AR, Bhat FA, Parveen N (2010) The ecology of macrozoobenthos in Shallabugh wetland of Kashmir Himalaya, India. Eco Nat Environ 2(5):84-91 
Srivastava N, Harit GH, Srivastava R (2009) A study of physicochemical characteristics of lakes around Jaipur. India J Environ Biol 30(5):889-894

Sundar ML, Saseetharan MK (2008) Ground water quality in Coimbatore, Tamil Nadu along Noyyal River. J Environ Sci Eng 50(3):187-190

Tiwari TN, Mishra MA (1985) A preliminary assignment of water quality index of major Indian rivers. Indian J Environ Proc 5:276-279

Vyas A, Mishra DD, Bajapai A, Dixit S, Verma N (2006) Environment impact of idol immersion activity lakes of Bhopal, India. Asian J Exp Sci 20(2):289-296

Wavde PN, Arjun B (2010) Groundwater quality assessment at Malegaon region of Nanded in Maharashtra (India). J Environ Sci Eng 52(1):57-60

WHO (2004) Guidelines for drinking-water quality, World Health Organization, 3rd edn, vol 1. Recommendations. Geneva, Switzerland, pp 515
Wilcox LV (1995) Classification and use of irrigation waters. US Department of Agriculture, Washington DC

Yu FC, Fang GH, Ru XW (2010) Eutrophication, health risk assessment and spatial analysis of water quality in Gucheng Lake, China. Environ Earth Sci 59:1741-1748. doi:10.1007/ s12665-009-0156-8

Zan F, Huo S, Xi B, Li Q, Liao H, Zhang J (2010) Phosphorus distribution in the sediments of a shallow eutrophic lake, Lake Chaohu, China. Environ Earth Sci. doi:10.1007/s12665-010-0649-5

Zhang Q, Li Z, Zeng G, Li J, Fang Y, Yuan Q, Wang Y, Ye F (2009) Assessment of surface water quality using multivariate statistical techniques in red soil hilly region: a case study of Xiangjiang watershed, China. Environ Monit Assess 152:123-131. doi: 10.1007/s10661-008-0301-y 